\title{
Lead Study Agent
}

National Cancer Institute

\section{Source}

National Cancer Institute. Lead Study Agent. NCI Thesaurus. Code C70844.

A primary medical product, practice, or application that is tested in a multi-agent clinical study. 